\title{
Early recovery of lymphocyte count after hematopoietic stem cell transplantation is a potential risk factor for chronic graft-versus-host disease
}

\author{
Masato Yanagi ${ }^{1}$, Ryoji Kobayashi ${ }^{2}$, Satoru Matsushima ${ }^{1}$, Daiki Hori ${ }^{2}$, Koya Kodama ${ }^{1}$, \\ Daisuke Suzuki ${ }^{1}$, and Kunihiko Kobayashi ${ }^{1}$ \\ ${ }^{1}$ Sapporo Hokuyu Hospital \\ ${ }^{2}$ Sapporo Hokuyu hospital
}

October 23, 2020

\begin{abstract}
Few studies have investigated the association between severity of lymphopenia and clinical outcome during chemotherapy or hematopoietic stem cell transplantation (HSCT). We investigated this issue by retrospectively analyzing pediatric patients who received allogeneic-HSCT (allo-HSCT) using a newly developed parameter called the LD-index that combines both the duration and the intensity of lymphopenia. A total of 92 patients underwent allo-HSCT in our hospital from April 2007 to August 2019. The median age at HSCT was 10.3 years (range $0.4-28.1$ ). The median LD-index was 9,285 (range $2,217-$ 36,064). A significantly high association was observed between the LD-index and the incidence of chronic graft-versus-host disease (GvHD) ( $\mathrm{p}=0.0045)$. Analysis of predictive factors for chronic GvHD was carried out using univariate analysis. Lower LD-index, donor source and duration (days) of lymphopenia were found to be significant factors associated with chronic GvHD. Multivariate analysis, however, only identified an association between lower LD-index and increased incidence of chronic GvHD $(\mathrm{p}=0.004)$. In conclusion, the duration and the intensity of lymphopenia after allo-HSCT have an effect on the development of chronic GvHD.
\end{abstract}

\section{Hosted file}

Text.pdf available at https://authorea.com/users/349380/articles/488506-early-recoveryof-lymphocyte-count-after-hematopoietic-stem-cell-transplantation-is-a-potential-riskfactor-for-chronic-graft-versus-host-disease

\section{Hosted file}

Table 1. Demographics and clinical characteristics of patients undergoing allo-HSCT.pdf available at https://authorea.com/users/349380/articles/488506-early-recovery-of-lymphocytecount-after-hematopoietic-stem-cell-transplantation-is-a-potential-risk-factor-forchronic-graft-versus-host-disease

\section{Hosted file}

Table 2. Analysis of the association between LD-index and various factors.pdf available at https://authorea.com/users/349380/articles/488506-early-recovery-of-lymphocyte-countafter-hematopoietic-stem-cell-transplantation-is-a-potential-risk-factor-for-chronicgraft-versus-host-disease

\section{Hosted file}


Table 3. Association between chronic GvHD and factors (Univariate analysis).pdf available at https://authorea.com/users/349380/articles/488506-early-recovery-of-lymphocyte-countafter-hematopoietic-stem-cell-transplantation-is-a-potential-risk-factor-for-chronicgraft-versus-host-disease

\section{Hosted file}

Table 4. Multivariate analysis of the association of chronic GvHD with various factors.pdf available at https://authorea.com/users/349380/articles/488506-early-recovery-of-lymphocytecount-after-hematopoietic-stem-cell-transplantation-is-a-potential-risk-factor-forchronic-graft-versus-host-disease
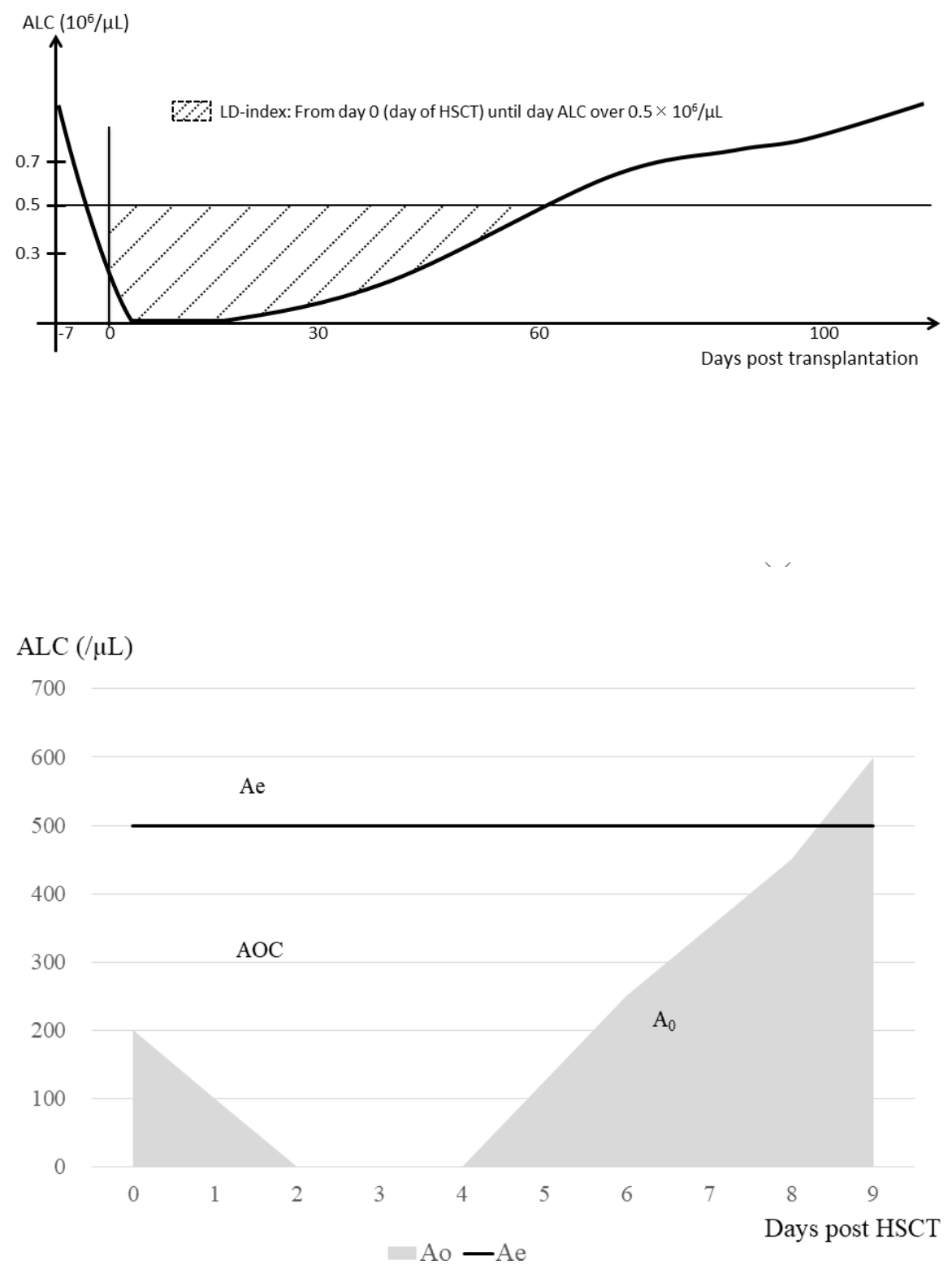